\title{
Research of the Current Situation and Future Trend of Internet Small-Credit Companies in China-Take Chongqing as a Case Study
}

\author{
Weiguo Qiu \\ Correspondence: Weiguo Qiu, Sichuan Institute of Administration, China. \\ Received: February 28, 2019 \\ Accepted: March 20, $2019 \quad$ Available online: April 15, 2019 \\ doi:10.11114/aef.v6i3.4210 \\ URL: https://doi.org/10.11114/aef.v6i3.4210
}

\begin{abstract}
In recent years, Internet finance has developed rapidly in China, benefiting from China's political, economic, social and technological environment. Taking Chongqing as an example, this paper analyses the current situation and the reasons behind the development of Chongqing Internet Microfinance Company, combining with the existing literature at home and abroad, as well as many excellent and enterprise cases such as Alibaba, Suning, Xiaomi, Jingdong, Baidu and so on. At the same time, it puts forward some thoughts on the future development of Internet microfinance companies.
\end{abstract}

Keywords: internet finance, petty loan, financing

\section{Introduction}

Internet finance was first included in the five-years plan of China on November 3, 2015. In July 4, 2015, "the guidance of the State Council on actively promoting the "Internet Plus" action" was officially released. The 11 directions of collaborative manufacturing, modern agriculture, intelligent energy and inclusive finance were included in the key areas of "Internet Plus" action, and will be promoted and supported by the state. "Internet +" finance has been upgraded to the national key strategy. "Internet Plus" finance is not a simple sum up of Internet technology and financial industry, but the basic functions of finance have undergone some profound changes after it has been integrated into the spirit of the Internet, especially Internet finance and Internet lending have carried out a series of innovations on financial models, serving the "small and medium" blue sea market and serving the real economy.

At present, The layout of the development of China's Internet finance is based on the third-party payment platform, and gradually develops more and more new models, such as $\mathrm{P} 2 \mathrm{P}$ online lending, crowd-funding, online financing, etc. It has become the main force of financial innovation, and also represents the direction of China's Internet finance development.

Internet finance is a concept with great flexibility and imagination. The rising and developing of Internet finance has a profound macro background. The development of Internet Finance in China and the macro-environment of the rise of Internet lending mainly include the following four aspects:

First, the political environment. At present, the development of China's economic has entered a new normal. The vast space of urbanization, the huge power of integration of "four modernizations", the huge market of consumption upgrading, the rapid development of technological innovation, and the potential of capital, labor and land have not been fully exploited, all of these need supporting financial services. The emergence and development of Internet Finance and Internet lending business plays a great role in promoting it. Development has played a great role in promoting it. Under the background of the new normal economy, the government actively guides Internet Finance and Internet lending to grasp the development opportunities, serve the real economy, serve small and medium-sized enterprises, and help China's economic transformation.

Second, the economic environment. The rapid development of small and micro enterprises will become the engine of the growth of China's economic, but at the same time, the phenomenon of lack of funds in small and micro enterprises is not-uncommon. The development of small and micro enterprises requires a large number of financial services, which is a financial business with great potential for development of the financial industry. At present, the development of Chinese traditional finance is facing a series of problems. The "pyramid" form of social and economic structure is contradictory to the "inverted pyramid" form of financial structure, which results in that small and micro enterprises can not obtain sufficient financial service support like large enterprises. The contradiction between them restricts the future development of China's micro-economy. The emergence of the Internet financial model provides new ideas for the development of the financial industry and small enterprises in the future. On the one hand, Internet enterprises such as 
Ali Group and Jingdong Group began to involve in Internet financial business and Internet lending business, on the other hand, the traditional financial industry is changing its development concept, realizing business internetization, focusing on the development of Internet finance, and accelerating the pace of adjustment of the entire industrial structure.

Third, the social environment. Internet is increasingly integrated into the lives of ordinary people. Mobile payment, search engines, social networks, big data, cloud computing and other Internet technologies will have a tremendous impact on the financial model. The integration of Internet and finance, especially micro-credit, is accelerating. China has 630 million Internet users, including 527 million Internet users through mobile terminals. According to CNNIC's "42nd Statistical Report on the Development of China's Internet", the scale of Chinese Internet Users was 802 million, the penetration rate of Internet reached $57.7 \%$, the scale of mobile Internet Users reached 788 million, and the proportion of Internet users using mobile phones was $98.3 \%$ by June 2018 , The popularity of the Internet has led to an exponential growth in the number of Chinese Internet Users. The advent of Internet financial products has enabled most Internet Users to participate in financial management easily and conveniently. The use of the Internet in the financial field will benefit a wide range of individual and enterprise users.

Fourth, the technological environment. The vigorous development of mobile internet, especially the rapid popularization of sensor devices and mobile devices, has made the whole society digitalized. Shopping, consumption, reading and many other activities are moving from offline to online. In the field of manufacturing, with the development of 3D printing, industrial production will also be transferred to online. At present, $70 \%$ of the social information has been digitalized, and the future may reach $90 \%$. The development of cloud computing provides the conditions for the processing of massive data. In the future, "Internet Plus" will become a new growth point of China's economy.

\section{Relevant Basic Theory and Literature Review}

The theory related to the development of Internet microfinance companies is financial innovation theory. Financial innovation in a narrow sense refers to the innovative development of financial products, and in a broad sense refers to the new creation and development of the entire financial industry and financial field, including the innovation of financial products, services, technology, institutions, and even financial theory and financial system. The definition of innovation is mainly derived from the viewpoint of Joseph Alois Schumpete, a famous Austrian-American economist, in Theory of Economic Development. Joseph Alois Schumpete (1912) defines innovation as: "Innovation refers to the establishment of new production functions, that is, entrepreneurs implement new combinations of enterprise elements." According to this view, innovation includes technological innovation (product innovation and process innovation) and organizational management innovation, because both of them can lead to changes in production function or supply function. Ye Shu (2010), a domestic scholar, defined financial innovation as: "Financial innovation is produced on the basis of adapting to the development of the economic situation and the diversified demands that accompany it. It is a series of changes and development of the whole financial system from the industrial system to the means of payment."

Mary J. Cronin (1997) , Rishab Aiyer Ghosh (1998) put forward the view for the first time: Internet-based financial products and services have brought more efficient and convenient banking services, fund services, insurance services, and other financial services to people's lives. With the transformation of the Internet financial model, Internet-based financial products and services will bring people benefits beyond economic benefits. It is a social return of intangible value. Dan J.Kim (2005) Lawrence J.Harte (2008) analyzed the application of Internet in financial market from the perspective of third party payment, and analyzed the development prospects of Internet finance. It was concluded that many Third Party Payment institutions have facilitated online transactions and created convenience for everybody's life. At the same time, Internet finance has brought new broad market and low cost to many enterprises and institutions.

Kauman (2000) believes that Internet finance can not only effectively reduce the time of loan approval and improve the efficiency of loan issuance, but also provide enterprises with lower financing costs than traditional financial institutions. Therefore, a large number of small and medium-sized enterprises excluded by traditional financial institutions will gradually turn to the Internet financial industry for financing. Manuchehr Sharokhi (2008) believes that Internet finance is the third type of financial model after the traditional financial intermediation and capital market. It can not only improve the transparency of financial information of enterprises, reduce various costs in the transaction process, but also form full competition in the financial industry, thereby improving the service awareness and service efficiency of traditional financial institutions. At the same time, Manuchehr Sharokhi also pointed out that Internet finance has a high demand for computer technology, and Internet finance must develop on the premise of ensuring network and data security. Dennis (2003) pointed out that compared with the traditional banking institutions which require enterprises to provide clear financial statements in their credit business, the advantages of Internet Finance lie in the absence of a large network, cumbersome procedures and lengthy processes. For small and medium-sized enterprises, its cost is low and its efficiency is high, which greatly reduces the burden of small and medium-sized enterprises. 


\section{Overall Development of Internet Small-Credit Company Companies in China}

In recent years, based on the continuous upgrading and expansion of consumer finance, enterprises with consumption scenarios, credit experience, Internet technology, traffic resources have applied for Internet small loan licenses. Compared with traditional small loan companies, Internet small loan company is not limited by the scope of registration, realizing cross-regional operation, greatly reducing the cost of customer acquisition. Therefore, the Internet lending is accelerating the layout.

According to the statistics of the People's Bank of China, by the end of 2016, there were 8673 microfinance companies in China, but only about 80 network microfinance companies, less than $1 \%$ of the number of microfinance companies. There is a huge space for the development of network small loan companies.

A total of 82 network microfinance companies (including planned companies) have been approved by 10 provinces and municipalities in China by March 2017. The top five: 30 in Guangdong, 18 in Chongqing, 11 in Jiangsu, 6 in Jiangxi and 5 in Zhejiang.

First, from the perspective of approved investors of Internet small loan companies, most of them are traditional small loan companies internetization (applying for Internet small loan licenses), and some of them directly initiate the establishment of Internet small loan companies. Among them, Internet enterprises and listed companies are the main applicants for Internet small loans. Forty-six listed companies have participated in the establishment of 50 Internet small loan companies (including companies that have obtained licenses to establishment but have not yet received financial approval). For example, Ali has obtained three licenses for Zhejiang and Chongqing respectively, CFPA Microfinance has two licenses for Chongqing and Hainan respectively, vipshop have two licenses in Guangzhou and Shanghai, while Jingdong will have three licenses in Beijing and Shanghai.

Secondly, in terms of the growth of Internet lending companies, Internet lending companies have developed rapidly (as shown in Figure 1), and generally slowed down after 2017.

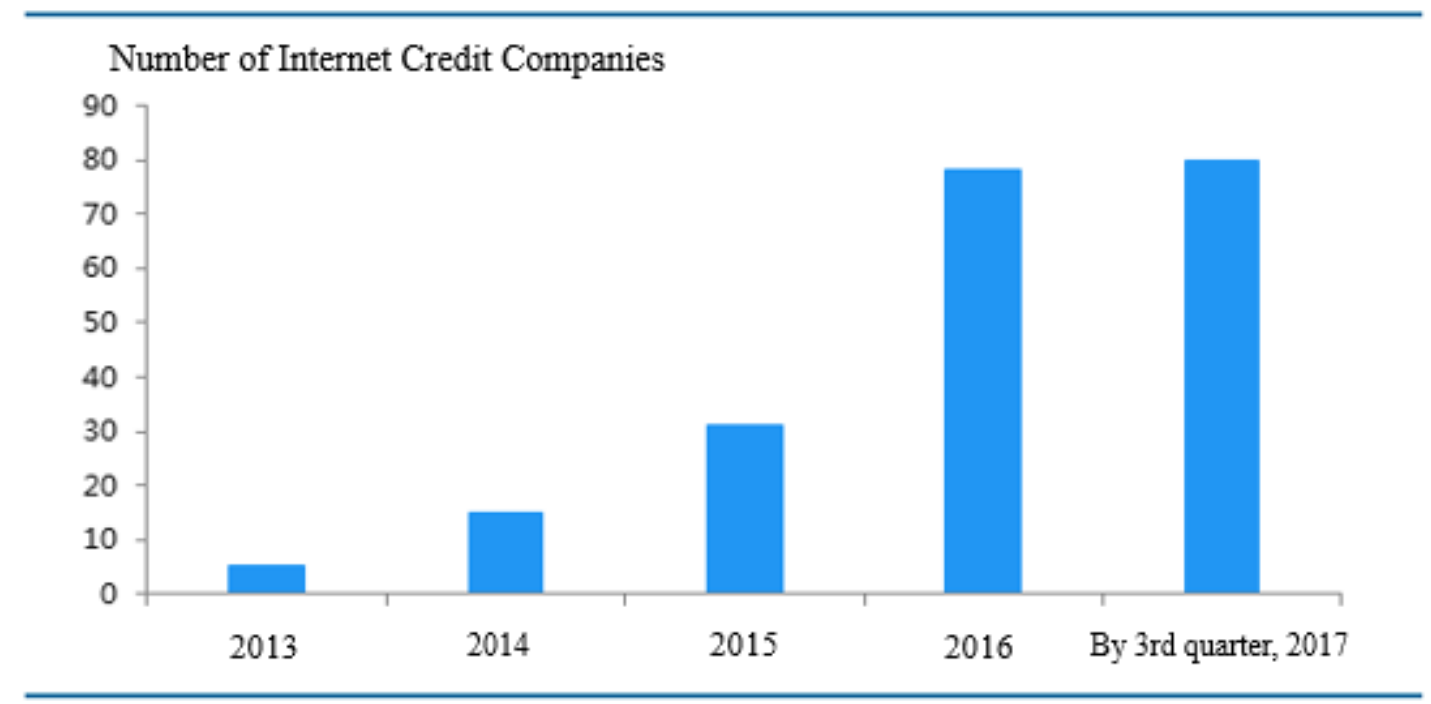

Figure 1. Growth of Internet Credit Companies

Third, from the point of view of geographical distribution, Internet small loan companies mainly gather in Guangdong and Chongqing. 
Number of Internet Credit Companies in different provinces

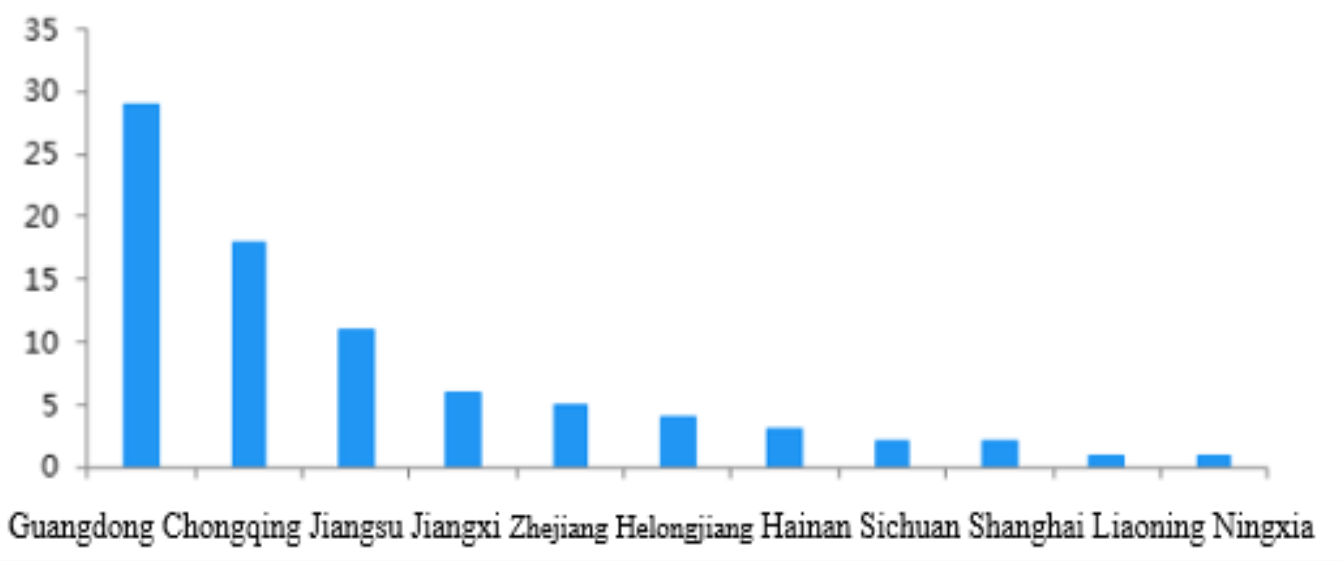

Figure 2. Geographical Distribution of Internet Small Credit Companies

164 licenses have been issued nationwide by July 8, 2017. Among 26 Internet loan sponsors in Chongqing, Alibaba, Jingdong, Baidu, Xiaomi, 58 Tongcheng and other Internet giants are included, while Guangzhou attracts 31 listed companies to set up 35 Internet loan companies, including vipshop, Lucia Lacarra, Tu Niu, The Same Trip Travel, and UTour Group. According to the incomplete statistics of the first consumer finance, 192 Internet small loan licenses had been issued nationwide by August 13, 2017. Among them, there are 32 in Chongqing and 49 in Guangdong.

\section{Deep Analysis of the Development of Internet Microfinance Companies: Taking Chongqing as An Example}

At the end of 2016, there were 272 small loan companies in Chongqing, including 18 Internet small loan companies. A total of 696.42 billion yuan of loans were granted throughout the year, and the non-performing loan rate remained at 4.9\%. By the beginning of July 2017, the loan balance of small loan companies had exceeded 100 billion yuan, adding 22.6 billion yuan, with an average loan balance of 459 million yuan. Balances, new additions and average loans ranked first in the country. There are 26 Internet small loan companies, ranking second in the country. Why do many well-known Internet companies choose Chongqing as the registered place of Internet small loans?

First, the requirement of registered capital is flexible. The minimum registered capital of poverty-stricken counties (including national and provincial levels) is RMB 100 million, other counties and districts outside the main urban area are 200 million yuan and the main urban area is 300 million yuan. The minimum registered capital for the establishment of a foreign-funded microfinance company is US\$30 million, and the proportion of foreign capital in a Sino-foreign joint venture microfinance company shall not be more than 50\%. At the same time, the proportion of controlling shareholders is not less than $20 \%$, and there is no lower limit for the proportion of non-controlling shareholders. Chongqing has 32 small lending companies with Internet credits, 20 of which are RMB-funded and 11 of which are US dollars-funded by August 2017. The average registered capital is about 620 million RMB. Among them, the highest registered capital is 2 billion yuan of Chongqing Ant Microfinance Co., Ltd.

Secondly, they focus on introducing well-known enterprises to settle down in Chongqing and set up internet small loan companies. Among the 32 small loan companies with network credits, 22 have listed company backgrounds, such as Ping An, Midea Group and Standard Chartered Group of China, as well as Internet giants such as Alibaba, Jingdong, Baidu and XiaoMi. Among the other 10, 5 have online or offline industry chain support, such as Suning group, Haier group, Leshi, XiaoMi mall, Guazi second-hand car selling net, MeiTuan, Witmart and XieXin industry. Chongqing prefers to issue licenses to listed companies, foreign companies, companies with online and offline scenarios or companies supported by industrial chains. 
Table 1. Some Well-known Internet Small Credit Companies in Chongqing

\begin{tabular}{|c|c|c|c|}
\hline Name & Registration Time & Registered Capital & $\begin{array}{l}\text { Industry Background and } \\
\text { Advantages }\end{array}$ \\
\hline $\begin{array}{l}\text { Jingdong Small Credit in } \\
\text { Chongqing }\end{array}$ & December 2015 & & $\begin{array}{l}\text { Rural financial services as } \\
\text { the core of management. } \\
\text { Using the Internet platform } \\
\text { of Jingdong Branch to } \\
\text { integrate } 200 \text { million users } \\
\text { and tens of thousands of } \\
\text { brand trading data of more } \\
\text { than } 3000 \text { county operation } \\
\text { centers, two major product } \\
\text { lines of agricultural credit } \\
\text { and agricultural product } \\
\text { credit are laid out. }\end{array}$ \\
\hline
\end{tabular}

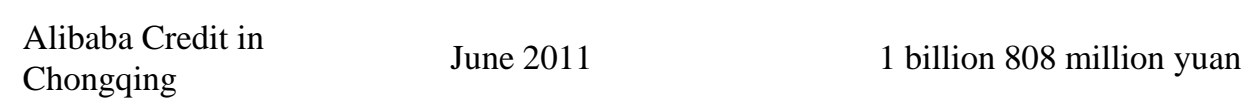

E-commerce platform, payment and micro-finance services such as small loans.

\begin{tabular}{llll}
\hline $\begin{array}{l}\text { Ant Small Credit in } \\
\text { Chongqing }\end{array}$ & & $\begin{array}{l}\text { Internet Finance, Payment } \\
\text { and Credit Reporting. }\end{array}$ \\
\hline Baidu Credit in Chongqing & October 2015 & 1 billion 300 million yuan & $\begin{array}{l}\text { Internet platform, financial } \\
\text { control group. }\end{array}$ \\
\hline XiaoMi small loan & June 2015 & 50 million dollars. & $\begin{array}{l}\text { Customized mobile phone, } \\
\text { mobile phone customer. }\end{array}$ \\
\hline Leshi small loan & March 2016 & 300 million yuan & Electrical retailers, offline \\
\hline $\begin{array}{l}\text { Chongqing Suning Small } \\
\text { Credit }\end{array}$ & December 2012 & 1 billion 200 million yuan
\end{tabular}

Relying on Haier Group's brand and taking Chongqing as its headquarters base, it goes deep into cities, counties and towns, establishes branches, and deeply meets the financing needs of small and micro enterprises. The main customers include 38000

Haier Internet Credit June $2014 \quad 50$ million dollars. distributors, small and micro businesses and individual business owners of Haier group. They also accept online and offline loan applications, adopt "mass customization" service mode, and are committed to local characteristics of industrial finance, supply chain finance, Internet + financial services. 
Table 1. Continued

\begin{tabular}{|c|c|c|c|}
\hline $\begin{array}{l}\text { Chongqing Midea Small } \\
\text { Loans }\end{array}$ & June 2017 & 300 million yuan & $\begin{array}{l}\text { Consumer appliances, } \\
\text { HVAC, robots and } \\
\text { industrial automation } \\
\text { systems. Providing } \\
\text { financial support and } \\
\text { inclusive financial services } \\
\text { to consumers around the } \\
\text { upstream and downstream } \\
\text { of the industrial chain. }\end{array}$ \\
\hline HanHua small loans & $\begin{array}{l}\text { September } \\
\text { Conversion to Internet } \\
\text { Credit in August } 2015\end{array}$ & & $\begin{array}{l}\text { Financial control group, } \\
\text { micro finance. }\end{array}$ \\
\hline $\begin{array}{l}\text { Shenzhou Digital Huicong } \\
\text { Credit }\end{array}$ & May 2014 & 1 billion yuan & \\
\hline $\begin{array}{l}\text { China Travel Security } \\
\text { Credit }\end{array}$ & November 2016 & & $\begin{array}{l}\text { Consumer finance business } \\
\text { and micro-supply chain } \\
\text { finance business with } \\
\text { tourism service as an } \\
\text { important scenario. }\end{array}$ \\
\hline $\begin{array}{l}\text { Chongqing Yonghui Small } \\
\text { Credit Company }\end{array}$ & March 2017 & 300 million yuan & Retailer \\
\hline $\begin{array}{l}\text { CFPA Microfinance small } \\
\text { loans }\end{array}$ & February 2017 & 100 million yuan & $\begin{array}{l}\text { CFPA Microfinance small } \\
\text { loans has established } 216 \\
\text { branches in } 19 \text { provinces, } \\
\text { municipalities and } \\
\text { autonomous regions, } 81 \% \\
\text { of which are in poor areas } \\
\text { at the national or provincial } \\
\text { level, and settled in } \\
\text { Chongqing in January } \\
\text { 2017. Focus on rural } \\
\text { microfinance. }\end{array}$ \\
\hline
\end{tabular}

Thirdly, supervision is relatively loose and policy support is strong.

The policy of issuing Internet small loan licenses is particularly noticeable. In November 2016, the Chongqing Finance Office issued the Notice: "Adjustment of the Regulations of the Chongqing Microfinance Company". In view of the regulation of financing business, they relax the management of financing interest rate and term of micro-loan companies. Both sides of the transaction through independent consultation to determine the financing interest rate and term, and adhere to the principle of marketization, at the same time the condition of rate of return on net assets has been cancelled. In addition, the network microfinance company established in Chongqing can handle self-financing business for the whole country through the network platform. It is reported that in addition to the above clear terms, Chongqing has other supporting policies for online small loan companies, so there are many companies rushing to Chongqing.

Based on the relaxed and preferential policy environment, Chongqing's small loan industry has developed rapidly, especially Haier Cloud Credit, a small loan company with risk control technology as its core competitiveness. Relying on Internet, big data, cloud computing and other technologies, Haier Cloud Credit's IT team built a multi-functional multi-link platform with payment, data interaction and other functions. By using the method of Iterative update, a set of solutions integrating customer management, risk control management, product management, approval management, pre-loan management, post-loan management, data center, third-party credit data and unified payment are customized, forming extraordinary ability of integrating into scene and linking. However, it is worth noting that the core technical members of Haier Cloud Loan in Chongqing come from Fudeng Small Loan in Chengdu. Chengdu has talents but can not retain them. The reason behind this is worth pondering.

First, in terms of the scope of lending, Chongqing has completely liberalized the restrictions of operating areas. Small loan companies can grant self-financing loans, entrusted loans and equity investments throughout the city, and small 
loan companies approved to start online lending businesses can issue self-financing loans to customers nationwide by network. In February 2017, the above mentioned scope of business was changed again. It is stated that small loan companies can carry out various loans, bill discount, asset transfer and equity investment with their own funds within the scope of Chongqing. Second, qualified microfinance companies can set up branches within and outside of the business areas they apply for. The scope of business of the branch is to handle self-financing loan and bill discount business, and the micro-loan companies that deal with off-line business can set up marketing department within and outside of their application area under certain conditions. The scope of business of marketing department is loan marketing and post-loan management. Third, there is greater flexibility in rate of leverage, cooperative financial institutions and financing interest rates. Since 2011, the first batch of small loan companies putting their assets profitability certificates and credit assets on line in Chongqing Financial Asset Exchange (the transfer of assets based on assignment of the right to benefit from creditor's rights receivable) have been an important innovation of Chongqing Municipal Government in supporting the development of small loan companies. It is of great significance for small loan companies to raise funds, which may be one of the important reasons for attracting small loan companies to enter Chongqing. Taking Chongqing XiaoMi Microfinance Company as an example, it has issued 2.7 billion yuan of ABS in 10 months. Among them, it issued 500 million yuan of ABS in October 2016, 300 million yuan of ABS in January 2017, 500 million yuan of ABS in March 2017, 600 million yuan of ABS in June 2017 and 800 million yuan of ABS in August 7th 2017. Fourth, preferential tax policies, small loan companies can enjoy pre-tax deduction of loan loss reserve income tax for financial enterprises, and financial capital risk compensation. Chongqing's "Key Points for the Supervision of Small Credit Companies in 2017" also shows that Chongqing will support the transformation of small credit companies, encourage the development of online lending business, and appropriately set up network micro-credit companies.

\section{Thoughts on the Future Development of Internet Microfinance Companies}

First, establish a practical and effective external regulatory mechanism. (1) The Financial Stability and Development Committee of the State Council should improve the supporting laws and regulations of non-deposit lending organizations represented by micro-loan companies as soon as possible, and make laws and regulations at the central level, so as to change the current situation of regulations of departments with low effectiveness and single standardization content, and realize that the inter-regional operation of Internet micro-loan companies can be governed by laws and regulations.(2) Local financial supervision departments timely update the work guidelines in practice, and put forward specific requirements for the large data platform, network customer resources, business system, registered capital, loan quota, compliance margin and off-site supervision system of Internet small loan companies. Through the Internet and big data technology, real-time monitoring of the operation of Internet small loan companies will promote the local financial supervision to turn to active and accurate.(3) Small loan associations actively perform their duties, strengthen industry self-discipline, help Internet small loan companies to interpret relevant policies and professional information, provide communication and contact with provincial and municipal small loan companies associations and economic organizations, deepen cross-regional exchanges and cooperation, organize exchanges of advanced industry experience, and encourage the improvement of innovation and profitability.

Second, improve the internal management system of Internet microfinance companies. (1) Strictly control the market access of Internet microfinance companies. The characteristics of Internet microfinance companies require their main sponsors to have strong financial strength, massive customers and online access channels. Therefore, the main sponsors of Internet microfinance companies must be Internet giants or industry leaders. In addition, its business needs to be scenario-based, designated use, customer constraints, mortgage. Internet microfinance companies, represented by many domestic Internet giants, such as Alibaba, Jingdong, Baidu and XiaoMi, have been well managed. (2) Employee staffing and pre-service training. First, qualified Internet microfinance companies must have good hardware conditions, staffing must include technical development, operation, product design, network security maintenance and other professionals with Internet development and operation capabilities. In addition, business managers need to do a good job of standardized audit procedures and training of ethical education, and timely change the concept of development of employees. (3) Never forget the essence of service and grasp the business characteristics of "Small, Fast, Flexible ". Internet microfinance companies should first be microfinance companies, and combine their own advantages, adhere to the principle of microfinance decentralization, fast, timely, flexible and simple. Internet microfinance should abandon the idea of making quick money and insist on taking small and medium-sized enterprises and low-income groups as the main body to provide short-term financing services to promote consumption and development of service entity.

Third, purifying and optimizing the financial environment for the operation of microfinance business. (1) Establishing information sharing platform. Provincial and municipal regulatory departments, financial industry associations and other industry organizations establish information sharing systems, strengthen horizontal interconnection and vertical collaboration and management, to find out the imperfect problems of the industry in time and actively follow up and solve them. For Internet microfinance companies that have irregularities (lack of risk control, issuing high-interest loans, 
irregularly lending funds to multi-borrowing customers, etc.), enforcement of law must be strict and strictly handled. (2) Incorporating into Credit Reporting Management System. Regulators represented by the People's Bank of China around the world should open or share credit information of enterprises and individuals, provide free inquiries to licensed Internet microfinance companies, and incorporate credit records of enterprises and individuals into the credit reporting system, and do a good job in credit reporting, rating and blacklist construction, so as to promote the development of the whole industry towards a more orderly and healthy direction. (3) Strengthening policy guidance and encouragement. At present, approval and daily supervision of Internet microfinance companies are mostly carried out by local governments. At the same time, local governments can also introduce some subsidiary incentive policies. For Internet microfinance companies that are well-managed and have good effect in supporting the development of real economy, they may have preferential policies and financial incentives.

\section{Reference}

Ajay, A., Christian, C., \& Avi, G. (2013). The Simple Economics of Crowd funding. Policy and Economy, 6.

Anait, K. P. (2003). Industry Self-regulation without Sanctions: The Chemical Industry Responsible Care Program. Academy of Management Journal.

Anthony, F. H., Acemogla, D., \& Aseman, O. (2001). Systemic Risk and Stability in Financial Networks. NBER working Paper.

Caprio, G., \& Klingebiel, D. (1996). Does Financial Re-form Raise or Reduce Saving? The Review of Economics and Statistics.

Dan, J., Kim, G., \& Jason, S. (2005). Recent developments in e-commerce. Tort Trial \& Insurance Practice Law Journal, 277-282.

Haizheng, L., Richard, W., \& Han, Z. (2010). Risk, Convenience, Cost and Online Payment Choice: A Study of E-Bay Transactions.

Iain, K., \& Manuchehr, S. (2008). Functionality and usability in design for e-Banking Services. Interacting with Computer.

Joseph, A. S. (1912). Theory of Economic Development. Anthropology Today, 1.

Mary, J. C. (1997). "Banking an Finance on the internet".

Nccusl, L., \& Harte, J. (2008). Uniform Money Services Act. Drafted by the National Conference of Commissioners on Uniform State Laws and by it Approved and Recommended for Enactment in All the States at its Annual Conference Meeting in its One-Hundred—and-Ninth Year, ST[J].

\section{Copyrights}

Copyright for this article is retained by the author(s), with first publication rights granted to the journal.

This is an open-access article distributed under the terms and conditions of the Creative Commons Attribution license which permits unrestricted use, distribution, and reproduction in any medium, provided the original work is properly cited. 